\title{
Tracing sediment sources in a tropical highland catchment of central Mexico by using conventional and alternative fingerprinting methods
}

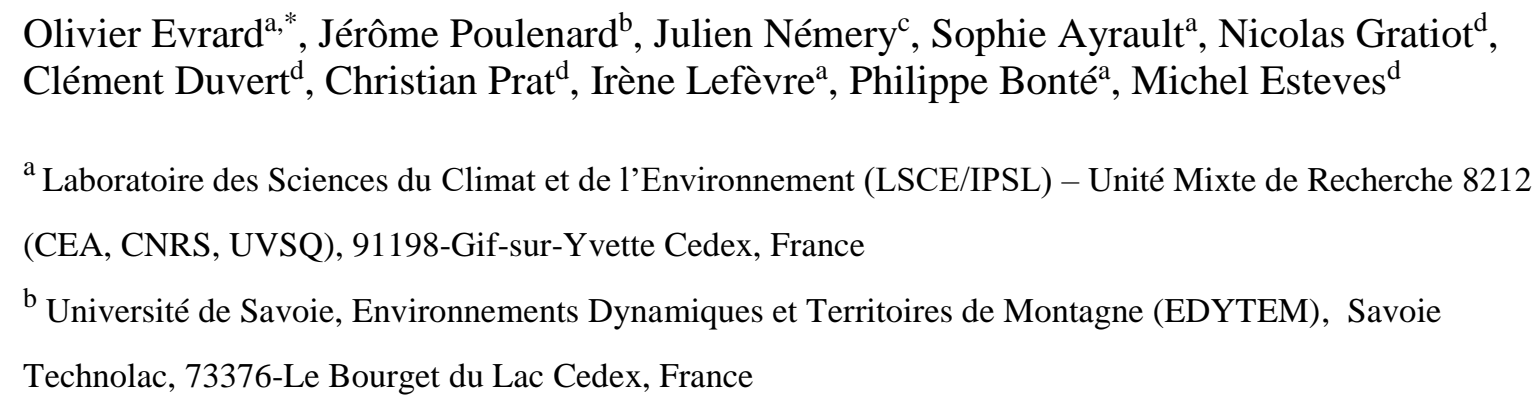
take the organic carbon content of soils into account and the difficulty to use geochemical properties to fingerprint sediment in very altered volcanic catchments. However, combining our fingerprinting results with sediment export data provided a way to prioritise the implementation of erosion control measures to mitigate sediment supply to the Cointzio reservoir supplying drinking water to Morelia city.

\section{Keywords}

Sediment; fingerprinting; soil types; Mexico; tropical catchment. 


\section{Introduction}

Land degradation is particularly severe in tropical regions, such as in Mexico (Descroix et al., 2008), in southern China (Barton et al., 2004) or in eastern Africa (Nyssen et al., 2004). In Mexico, overgrazing, deforestation, and the intensification of food crop cultivation have led to severe erosion and to a decline in soil fertility (Roldán et al., 2003). Furthermore, once it reaches the river, sediment leads to numerous problems in downstream areas (Owens et al., 2005). It causes for instance an increase in water turbidity and a rapid filling of reservoirs (Syvitski et al., 2005). Sediment is also associated with numerous contaminants (e.g., metals, organic compounds, antibiotics, radionuclides; e.g., Tamtam et al., 2011; Le Cloarec et al., 2011). Their integration into the food chain can lead to public health problems after the consumption of contaminated fish (Sánchez-Chardi et al., 2009; Urban et al., 2009). Sediment also conveys nutrients, and soil erosion and deposition play therefore a significant role in global biogeochemical cycles (Quinton et al., 2010). Furthermore, in mountainous environments, the problems associated with erosion and sedimentation are exacerbated by the large quantities of sediment produced within very short periods (Meybeck et al., 2003; Mano et al., 2009).

Sediment supply to the river needs to be controlled to prevent these problems. However, there is a preliminary need to determine the main erosion sources to implement appropriate and effective erosion mitigation measures. In tropical areas such as the highlands of central Mexico where hydrology is controlled by the succession of a dry and a rainy season, it is generally assumed that the increase in discharge at the beginning of the rainy season can lead to an important resuspension of sediment accumulated in the river channel (e.g. Susperregui et al., 2009). Evrard et al. (2010) showed that the first storms of the year exported the bulk of the sediment stock accumulated in the river channel during the previous rainy season. However, this study also outlined that sediment can also be directly eroded from hillslopes and exported from small $\left(3-12 \mathrm{~km}^{2}\right)$ catchments during individual heavy storms. Furthermore, the contribution of different sediment source areas (e.g., historical gullies vs. cropland) was suspected, but it remained to be quantified in order to prioritise the implementation of erosion control measures.

We propose to use two different sediment fingerprinting techniques to outline the main sources of sediment within those catchments. The fingerprinting method consists in tracing conservative sediment properties or characteristics that can be identified in both catchment sources and sediment delivered downstream (Walling, 2005). So far, very few fingerprinting 
studies have been conducted in tropical regions (see for instance Collins et al., 2001, in a catchment of Zambia). Fingerprinting generally requires a multi-tracer approach. Besides 'conventional' fingerprinting based on the measurement of radionuclides and geochemical elements, alternative fingerprints have been recently used such as sediment colour properties (Martínez-Carreras et al., 2010a, b) and Diffuse Reflectance Infrared Fourier Transform Spectroscopy (DRIFTS; Poulenard et al., 2009; Poulenard et al., in press) to trace the origin of suspended sediment transported by rivers.

In this context, we conduct two independent fingerprinting exercises (i.e., the conventional approach based on radionuclide and geochemical concentrations, and the alternative DRIFTS method) to quantify sediment sources in three small tropical catchments of the Mexican Central Highlands. Those three areas cover the range of land use, topographic gradients and soil conditions of the potential areas delivering sediment to a reservoir providing $25 \%$ of the water distributed in the region of Morelia city (ca. 1,000,000 inhabitants). The implications of the sediment fingerprinting results to control reservoir siltation will also be discussed. Factors controlling sediment fluxes exported from those catchments and sediment transfer times within those areas are discussed elsewhere (Duvert et al., 2010, 2011; Evrard et al., 2010).

\section{Materials and methods}

\subsection{Study area}

The Cointzio catchment covers an area of $630 \mathrm{~km}^{2}$ located in the transverse volcanic belt of central Mexico (Fig. 1). The catchment bedrock consists of igneous rocks generated by Quaternary volcanic activities. Soils within the catchment are mainly Acrisols on the hillsides, Andisols in headwater areas and Luvisols in the plains (FAO, 2006). The river network is dominated by the Grande de Morelia River. A dam is located at the outlet of the catchment, $13 \mathrm{~km}$ upstream of Morelia city (ca. 1,000,000 inhabitants). This dam was built in 1940 to supply water for domestic consumption as well as for industrial and agricultural activities. The Cointzio reservoir $\left(4 \mathrm{~km}^{2} ; 65 \times 10^{6} \mathrm{~m}^{3}\right)$ undergoes significant sedimentation, which has led to a severe deterioration of environmental conditions in the lake (Ramirez-Olvera et al., 2004 ) and to a $20 \%$ loss of its water storage capacity since its construction (Susperregui et al., 2009).

Three subcatchments representative of the various land use, slope gradients and soil conditions found in the Cointzio catchment were monitored in the framework of this study: 
110 Huertitas $\left(3 \mathrm{~km}^{2}\right)$, La Cortina $\left(9 \mathrm{~km}^{2}\right)$ and Potrerillos $\left(12 \mathrm{~km}^{2}\right.$; Fig. 1). Their characteristics

111 are described in Table 1. In addition, we monitored the river discharge and sediment fluxes in

112 Santiago Undameo, at the outlet of the entire catchment, just upstream of Cointzio reservoir

113 (Gratiot et al., 2010; Duvert et al., 2011). It is important to note that villages located within

114 the catchment are not equipped with sanitation systems and that they directly discharge their

115 wastewater into the river network.

\subsection{Field measurements}

\section{Rainfall and discharge}

120 Rain gauges and river monitoring stations were installed in the three subcatchments (Fig.

121 1). They provided continuous precipitation and water discharge data derived from continuous

122 water level measurements (with a 5-min time step) obtained with a Thalimede OTT water-

123 level gauge, and discharge calculated using stage-discharge rating curves (see Duvert et al.,

124 2010, for details on this method).

Measurement of SSC

At the outlet of each subcatchment, data on Suspended Sediment Concentration (SSC; g $\mathrm{L}^{-1}$ ) were obtained using an automatic water sampler (ISCO 3700) triggered by water level variations. During floods, water samples were collected after each $5-\mathrm{cm}$ water level variation.

130 This sampling frequency was selected based on the mean characteristics (i.e., flood duration, 131 shape of rising and falling limbs) of the floods recorded previously (i.e., between 2006 -

132 2008; Duvert and Gratiot, unpublished data) in the subcatchments to obtain a trade-off

133 between a satisfactory flood coverage and a reasonable amount of samples to collect in the

134 field (see Duvert et al., 2010 and Duvert et al., 2011 for details).

135 SSC (generally $\geq 2 \mathrm{~g} \mathrm{~L}^{-1}$ ) was estimated at the laboratory after drying the entire sample for 13624 hours at $60^{\circ} \mathrm{C}$. For each flood, a composite sample was prepared by mixing all the 137 available individual samples. This provided a mean representative sample of each individual 138 flood with a sufficient quantity of fine sediment $(2-50 \mathrm{~g})$ to conduct radionuclide and 139 DRIFTS analyses. Details on the calculation of sediment fluxes at the outlet of the different 140 subcatchments can be found in Duvert et al. (2010). In total, 40 events that occurred between 141 May and November 2009 were sampled throughout the rainy season at the outlet of the three 142 subcatchments. 


\section{Soil collection}

Soil representative of the different land uses (i.e., gullies, cropland, woodland) observed in the three subcatchments was collected. Sampling was concentrated in potential sediment source areas (i.e., sites sensitive to erosion, and potentially connected to the river network). For each potential source (i.e., gullies, cropland, woodland), we collected five samples of surface material potentially submitted to erosion processes and connected to the river (top 0-5 cm; i.e. $0-2 \mathrm{~cm}$ at most locations and $0-5 \mathrm{~cm}$ where the erosion extent warranted a deeper sampling depth) and mixed them well to provide a homogeneous sample. In total, 17 representative composite samples were collected in the field between June and November 2009 (Fig. 1). This number of sources samples is rather limited, mainly due to practical and logistical reasons, but stress was laid in the field on providing representative samples of each land use class. In ideal conditions, more samples could have been collected. If we were aiming to discriminate the contribution of different lithological sources to suspended sediment, it would not have been enough to capture the within-source variability of fingerprint properties. However, this study aims to discriminate land use sources. We will therefore add a step to the conventional fingerprinting procedure by selecting the most relevant tracers from a physiochemical point of view to achieve this specific objective.

Furthermore, riverbed sediment was collected on exposed sites located along the main river channel network, using non-metallic trowels in order to avoid sample contamination. Several subsamples ( 10) were collected in January 2008 and in June 2009 at each of the 18 locations selected along the river network. They were used to prepare composite samples representative of the sediment deposited on the riverbed.

\subsection{Soil and sediment analysis}

\section{Radionuclide measurements}

All suspended sediment and soil samples were dried and sieved $(<250 \mu \mathrm{m})$ before analysis. To check that grain size of particles remained similar between soil and sediment samples, grain size distribution was determined with a Malvern ${ }^{\circledR}$ particle size analyzer after being submitted to a 10 -min ultrasonic agitation.

Fallout and geogenic radionuclides were measured in all the collected samples ( $n=55$ with 17 composite soil samples, 18 composite riverbed samples and 20 composite suspended sediment samples), whereas the analyses of elemental geochemistry were carried out on a selection of samples ( $n=37$, i.e. 17 composite soil samples and 20 composite suspended 
sediment samples). For the measurement of radionuclides in each sample, soil and sediment were placed in a counting box. Fallout (Am-241, Be-7, Cs-137, Pb-210) and geogenic (K-40, Ra-226, Ra-228, Th-228, Th-234) radionuclide concentrations were determined by gammaspectrometry using the very low-background coaxial N- and P-types GeHP detectors (Canberra / Ortec) available at the Laboratoire des Sciences du Climat et de l'Environnement (Gif-sur-Yvette, France). "Excess" ${ }^{210} \mathrm{~Pb}\left({ }^{210} \mathrm{~Pb}_{\mathrm{xs}}\right)$ was calculated by subtracting the supported activity (determined using two ${ }^{238} \mathrm{U}$ daughters, i.e. ${ }^{214} \mathrm{~Pb}$, by taking the average count number at 295.2 and $351.9 \mathrm{keV}$, and ${ }^{214} \mathrm{Bi}$ at $609.3 \mathrm{keV}$ ) from the total activity of ${ }^{210} \mathrm{~Pb}$ (measured at $46.5 \mathrm{keV})$. Efficiencies and background levels of the detectors were periodically controlled with internal and IAEA soil and sediment standards. Radionuclide activities were systematically corrected taking account of the decay after the sampling period.

\section{Geochemical measurements}

For the measurement of elemental geochemistry, Rare Earth Elements (REE; i.e., Ce, Eu, $\mathrm{La}, \mathrm{Lu}, \mathrm{Sm}, \mathrm{Tb}, \mathrm{Yb})$, three major elements $(\mathrm{Fe}, \mathrm{K}, \mathrm{Na})$ and ten trace elements (As, Ba, Co, Cr, Cs, Hf, Sc, Ta, Th, Zn) were analysed by Instrumental Neutron Activation Analysis (INAA). Dried subsamples (ca. 40-80 mg) were packed into tightly closed plastic bags, without any preliminary digestion. The subsamples were exposed to irradiation at the experimental nuclear reactor Orphée of the Commissariat à l'Energie Atomique (CEA; Saclay, France). The subsamples underwent a flux of thermal neutrons of $2.13 \times 10^{13} \mathrm{n} \mathrm{cm}^{-2} \mathrm{~s}^{-1}$ during 30 minutes. After a 4-days cooling, four successive measurements of gamma activities were carried out using HPGe detectors. Two reference materials (i.e., IAEA SL-1 and Soil-7) were systematically used to cross-check the results. Uncertainty on these measurements is $\leq$ $5 \%$.

\section{Carbon and Nitrogen content measurements}

Soil and suspended sediment content in bulk Carbon (C) and Nitrogen (N) was measured by CHN analysis using a CN-analyzer FlashEA 1112 (Thermo Fisher Sci., MA, USA) at the Laboratoire d'Ecologie Alpine (LECA; Grenoble, France). About $20 \mathrm{mg}$ of each sample were burnt at high temperature with a catalyser under helium flux, to transform total $\mathrm{C}$ into carbon dioxide and total $\mathrm{N}$ into $\mathrm{N}_{2}$. Obtained $\mathrm{CO}_{2}$ and $\mathrm{N}_{2}$ were separated using a gas chromatography column and analysed by thermal conductivity detector. Results are expressed in $\% \mathrm{C}$ and $\% \mathrm{~N}$. Soil content in carbonates was analysed at the INRA soil analysis laboratory in Arras (France) using classical calcimetric method (Robertson et al, 1999) according to the normative procedure NF ISO 10693. Results are expressed in \% $\mathrm{C}\left(\mathrm{CaCO}_{3}\right)$. 
Furthermore, $\delta^{13} \mathrm{C}$ measurements were conducted to outline potentially different 214 contributions of avocado fields and maize fields, based on the difference in the stable carbon 215 isotope signatures between C3 and C4 plants (Balesdent and Wagner, 1988). $\delta^{13} \mathrm{C}$ analyses 216 were conducted on representative samples from (i) maize fields and (ii) avocado fields from

217 La Cortina subcatchment to test the potential discrimination between both sources. Analyses 218 were conducted at LSCE on an EA-IRMS devoted to organic samples (Thermo Fischer 219 Delta+XP).

A ThermoNicolet 380 spectrometer equipped with a liquid-nitrogen cooled MCT

223 (Mercury - Cadmium - Telluride) detector was used to perform the Fourier Transform

224 Infrared (FT-IR) analysis of soil and suspended sediment. Spectra were obtained using the

225 diffuse reflectance (DRIFTS) measurement technique. The spectra scan range was $4000-650$

$226 \mathrm{~cm}^{-1}$ at a resolution of $2 \mathrm{~cm}^{-1}$ with 32 co-added scans per spectrum. Results were then

227 compiled using the OMNIC $\odot$ (version 7.3) software provided by the spectrometer

228 manufacturer (ThermoNicolet, USA). This software facilitated measurement of the peak areas

229 that were relevant to determine the DRIFTS signatures.

\subsection{Statistical analyses and sediment tracing}

232 Conventional mixing model

233 The different sediment source types were characterised by their mean concentration 234 and by the standard deviation of each of the 29 radionuclide and geochemical properties 235 measured in the samples. The ability of the 29 potential fingerprinting properties to 236 discriminate between the potential sediment sources was investigated by conducting a 237 Kruskal-Wallis $H$-test as initially proposed by Collins and Walling (2002). Based on the set of 238 discriminating properties retained, an optimum 'composite fingerprint' was identified by 239 performing a stepwise selection procedure. This procedure consisted in minimising Wilk's 240 lambda, as suggested by Collins and Walling (2002). Then, we constructed a Monte Carlo 241 mixing model to quantify the range of contribution of each sediment source to the sediment 242 samples collected at the different stations. Details on this model can be found in Evrard et al. 243 (2011). 
In each subcatchment, two main types of potential sediment sources were considered (see the land use classes mentioned in Table 2). Two to six soil samples of each source were mixed in equal proportions to constitute a unique reference sample for the corresponding source type. In subsequent steps, those reference samples were mixed in various weight proportions. A DRIFTS spectrum was obtained for each mixture. The number of mixtures prepared in each case varied between 20 and 30. This choice was dictated by (i) the previous experiments showing that the chemometric models can be built based on the analyses of 20 to 30 mixtures (Poulenard et al., 2009 ; Poulenard et al., in press) and (ii) the willingness not to over complicate the procedure when applying the DRIFTS-PLS method to several subcatchments. Relationships between DRIFTS spectra (' $x$ ' variate) and the corresponding weight contribution of the sediment source datasets (' $y$ ' variate) were analysed using Partial Least Square (PLS) analyses. Approximately $75 \%$ of samples were used to develop the calibration models, whereas the remaining $25 \%$ were used for validation. In order to get rid of the small differences due to uncontrolled sources of variation, data pre-processing methods were applied to the spectra, such as baseline correction, Savitzky-Golay smoothing, mean centering, variable scaling, multiplicative signal correction (MSC) and standard normal variate (SNV). The procedure followed by Poulenard et al. (2009; in press) was used to determine the number of components providing the best compromise between the description of the calibration set and the model predictive power, i.e. the lowest predictive standard error (PRESS).

The predictive performance of the models was evaluated by calculating several standard indicators such as the root-mean-square error of calibration (RMSEC), the rootmean-square error of cross-validation (RMSECV), the root-mean-square error of prediction (RMSEP), and coefficient of determination $\mathrm{R}^{2}$ of predicted values against reference data. Model validation was performed by both cross-validation and validation. RMSECV and RMSEP values provided the average uncertainty that can be expected for predictions of future samples. This uncertainty is only associated with the use of PLS models. Additional uncertainty associated with the application of this model to suspended sediment could not be taken into account.

Two independent PLS models were constructed to estimate the proportion of sediment originating from the main potential sources in each subcatchment. DRIFTS spectra of suspended sediment were then introduced into these PLS models to estimate the contribution of each sediment source and the associated uncertainty (Poulenard et al., in press). 


\section{Results}

\subsection{Quantifying the contribution of sources delivering sediment to the river}

Overall, soils of the catchment are characterized by very low concentrations in geochemical elements and carbonates $(<0.01 \%$ ) (Table 2$)$. These low levels reflect the strongly weathered character of soils in this highland volcanic region of central Mexico. This strong alteration is confirmed by the low content of soils in elements such as $\mathrm{K}, \mathrm{C}$ and $\mathrm{N}$ in degraded soils and gullies (Table 2) as already reported by Bravo-Espinoza et al. (2009). Furthermore, the bulk of $\mathrm{C}$ content in soils is mainly under organic form as previously observed in the same study area (Cavoleda et al, 2011). In this context and to provide a strong physiochemical basis to our conventional fingerprinting exercise, we decided to restrict our fingerprint property selection to the fallout radionuclides and the biogenic elements. Fallout radionuclides such as ${ }^{137} \mathrm{Cs}$ and ${ }^{210} \mathrm{~Pb}$ xs can indeed provide a powerful tracer to discriminate between surface and subsurface (i.e., gully) sources (Wallbrink and Murray, 1993). Biogenic elements (e.g., C, N) can also provide this information, provided they are used to quantify the sources of suspended sediment to ensure that the conservation of those properties is achieved during the rapid transfer of particles to and within the river (Collins and Walling, 2002).

Conservation of particle grain size during their transfer between the sources and the river constitutes another prerequisite of the fingerprinting method to verify. Particle size was constant in 2009 at the outlet of each subcatchment, as demonstrated by the median particle size (d50) of sediment collected in Huertitas $(10 \pm 1 \mu \mathrm{m})$, Potrerillos $(12 \pm 4 \mu \mathrm{m})$ and La Cortina $(26 \pm 6 \mu \mathrm{m})$. Furthermore, those values are very close to the median sizes of particles measured in the soil samples (Tables 2 and 3).

Conventional fingerprint properties retained to discriminate sediment sources in the three subcatchments are provided in Table 4. Performance of predictive models used for the DRIFTS approach are given in Table 5. The PLS model, based on soil mixture analyses, was robust despite the limited number of samples analysed (Table 5). The correlations between actual and predicted proportions are excellent with $\mathrm{R}^{2}$ close to 1 for all the models. The RMSEP (average difference between prediction and actual value on the set of calibration i.e., not used to build the model) remains close to $10 \%$. This is acceptable given that our study

311 only aimed at obtaining an order of magnitude of the contribution of different sources

312 delivering sediment to the river. 
This subcatchment exported large quantities of sediment $\left(900-1500 \mathrm{t} \mathrm{km}^{-2} \mathrm{y}^{-1}\right.$; Duvert et al., 2010). Active gully networks provided a constant source of sediment. Our

318 fingerprinting analyses showed that sediment collected at the outlet during the 2009 rainy season was mostly supplied by the extended gully network of this subcatchment. This contribution varied between $72 \pm 10 \%$ and $100 \pm 12 \%$ according to the model based on spectroscopic properties, and between $88-98 \%$ according to the conventional mixing model (Figure 2). The low content in $\% \mathrm{C}$ (about $1 \%$ ) and in $\% \mathrm{~N}$ (about $0.08 \%$ ) of sediment during floods illustrates that most of the sediment originated from gully soils poor in $\mathrm{C}$ and $\mathrm{N}$. Sediment supply by cropland slightly decreased throughout the rainy season, which probably reflects the effect of vegetation growth that protected the soil against rainfall splash effect and erosion. During the most erosive storms (e.g., on 3 September), sediment was almost only supplied by gullies. Results provided by both spectroscopic and "conventional" fingerprinting techniques are consistent.

\section{La Cortina}

This subcatchment exported low quantities of sediment (ca. $30 \mathrm{t} \mathrm{km}^{-2} \mathrm{y}^{-1}$; Duvert et al., 2010). An attempt was made to differentiate the contribution of different vegetation types

334 based on their stable carbon isotopic signature but we could not outline any different contribution of maize and avocado fields. However, test analyses showed that $\delta^{13} \mathrm{C}$ value in river sediment $(-22.22 \pm 0.15 \%$ ) was close to cropland value (between $-22.31 \pm 0.10 \%$ and $21.86 \pm 0.10 \%)$ and significantly different from the woodland value $(-26.60 \pm 0.10 \%)$. DRIFTPLS model showed that 70 to $80 \pm 20 \%$ of the suspended sediment was provided by cropland without significant differences all throughout the season (Figure 3). The mixing model based on conventional fingerprinting properties similarly showed that $50-85 \%$ of sediment was supplied from cropland area. This result is consistent with the mean content in carbon $(6.5 \%)$ and nitrogen $(0.4 \%)$ of sediment during flood that is very close to the mean content measured in soils ( $\% \mathrm{C}=6.31$ and $\% \mathrm{~N}=0.43)$ (Table 2). Sediment export was higher during the first months of the rainy season because vegetation growth has progressively protected the soil against erosion and because the first storm of the rainy season flushed the sediment stock accumulated on the riverbed as demonstrated by Evrard et al. (2010).

\section{Potrerillos}


Sediment source contributions varied strongly throughout the rainy season. This subcatchment was characterized by large sediment exports $\left(600-800 \mathrm{t} \mathrm{km}^{-2} \mathrm{y}^{-1}\right.$; Duvert et al., 2010). A rapid succession of several storms was observed in this catchment in 2009 that was characterized by a strong reactivity and a "sawtooth behaviour". Sediment was delivered by both gullies and rangeland, in variable proportions (Figure 4).

Results provided by both fingerprinting techniques differ, mainly for 3 to 4 events (Figure 4). Conventional fingerprinting showed a strongly variable supply of sediment by gullies (5-86\%) and rangeland (14-95\%) all throughout the season. A very variable sediment supply by gullies (36-97\%) was also outlined by the DRIFTS approach. This bias is partially explained by the relationships observed between the contribution of the topsoils in rangeland determined by DRIFTS-PLS model and the organic carbon content of suspended sediment (Figure 5). The mid-infrared signature and thereby the results of DRIFTS-PLS were clearly influenced by the organic carbon content originating from the topsoil horizons. The DRIFTSPLS model provided in this case discrimination between the relative contribution of topsoils (relatively rich in organic matter; Table 2) and the deep horizons of gullies depleted in organic matter. During the first flood of the season, river sediment sample was characterized by a very high C content ( $2 \%$ vs. $0.3-0.8 \%$ during the rest of the season; Fig. 5). This is probably due to the export of cow dung stored on the soil surface by the first heavy storm of the season. This indicates that, at the beginning of the rainy season, an important stock of sediment and organic matter can be easily mobilized. This stock is probably accumulated during the dry season due to the combined effect of cattle grazing and trampling of the soil.

\subsection{Origin of sediment along the river network}

Overall, concentrations in geochemical elements and activities in radionuclides are very low in all the riverbed sediment collected along the river network of the entire catchment (data not shown). Various ratios between geochemical elements and radionuclides were calculated but they did not provide a way to outline specific sediment contributions within the catchment. However, farming practices such as application of fertilizers and pesticides can affect the composition of agricultural soils and sediment (Bravo-Espinoza et al., 2009). Phosphate fertilizers contain indeed 10 - 200 times more U than soils, whereas they have a lower Th content than soils (Takeda et al., 2004). The U/Th ratio can therefore provide a way to outline the supply of sediment by agricultural soils along the river network. Figure 6 illustrates that $\mathrm{U} / \mathrm{Th}$ ratio gradually increased from headwaters to the Cointzio reservoir. We 
hypothesize that this observation reflects the increase in sediment supply by agricultural areas along the river network. This hypothesis is consistent with the more detailed fingerprinting results available for the three subcatchments (Fig. 6): (i) U/Th ratio is high in sediment collected at the outlet of La Cortina where the bulk of material was supplied by cropland; (ii) U/Th ratio was lower at the outlet of Potrerillos where a mixed contribution of gullies and rangeland was outlined and (iii) U/Th ratio was the lowest at the outlet of Huertitas where sediment was almost exclusively provided by the gully network.

\subsection{Origin of sediment at the catchment outlet}

Based on the previous work conducted in the subcatchments, we wanted to outline the origin of suspended sediment collected at the river station draining the entire catchment and located just upstream of Cointzio reservoir. We chose to discriminate the sediment delivered by Acrisols (i.e., dominant type in Huertitas and Potrerillos) from sediment supplied by Andisols (i.e., dominant type in La Cortina). Reference Acrisols were taken from Huertitas gullies, whereas reference Andisols consisted of cropland soil (i.e., corn and avocado fields) from La Cortina. Infrared spectrum of Acrisols was characterized by the dominance of kaolinite in the clay fraction with three classical bands in the $3600-3700 \mathrm{~cm}^{-1}$ area. In contrast, Andisol spectrum was associated with gibbsite characteristic bands (Figure 7).

When compared to those source spectra, the infrared spectra of suspended sediment collected at Santiago Undameo station were very similar to the Acrisol spectra. The PLSDRIFTS model confirmed the dominance of the contribution of Acrisols delivering more than $70 \%$ of the suspended sediment conveyed by the river at that location. This proportion can even reach $90 \%$ during most of the rainy season during which $99 \%$ of sediment are exported to the lake (Figure 8). In contrast, during the dry season, the PLS-DRIFT model indicates that the sediment delivery from cultivated Andisols is higher and can reach up to $30 \%$ of total sediment, but this sediment corresponds to only $1 \%$ of the annual export from the entire catchment, which is negligible. Furthermore, those low water periods also coincide with the highest organic carbon concentrations measured in river sediment (Figure 8). This carbon is 413 likely to originate from local villages that are not equipped with sanitation systems. In 414 contrast, during high flow periods, river sediment is characterised by very low carbon contents, which is consistent with a dominant sediment supply by Huertitas or Potrerillos-like 
could then reflect a bias of the DRIFT-PLS approach induced by this strong increase in the organic carbon content of sediment during the dry season.

\section{Discussion}

\subsection{Sediment tracing methods}

The low concentrations in geochemical elements made it difficult to outline significant composition differences between different types of sources (e.g., soil types). In contrast, low activities in fallout radionuclides provided an efficient way to discriminate between different types of sources (typically gullies vs. cropland surface sheet erosion) when low-background and efficient gamma spectrometry detectors are available to conduct measurements. The results obtained in this study confirmed the preliminary observations made by Evrard et al. (2010) on potential sediment sources based on the Cs-137 activities in soils and sediment.

The DRIFT-PLS method provided results that are very consistent with the conventional geochemical approach in the context where minerals provide a dominant signal to the soil. In these contexts, with very distinct mineralogy, a simple qualitative comparison of infrared spectra provided a fast way to identify the dominant sediment sources. The dependence of the infrared method to the soil content in organic matter has facilitated sediment source apportionment in Potrerillos catchment, where it outlined the relative important contribution of surface (cropland) and depth (gullies) material, which was consistent with the carbon content of exported sediment. However, during the low stage period, the introduction of one source of soluble organic matter delivered by anthropogenic activities that is likely to have sorbed onto suspended sediment led to an overestimation of the contribution of surface soil to river sediment, given that they were the only sources included into the model and containing a large organic carbon content.

\subsection{Soil conservation in highland tropical catchments of central Mexico}

Our results have clear and significant management implications to control erosion and reservoir siltation in this Mexican catchment. It is important to highlight that high turbidity levels are observed at a regional scale in lakes and reservoirs of the Mexican central plateau (Merino-Ibarra et al., 2007; Bravo-Inclan et al., 2008 ; Severo et al., 2002). However, none of them attenuates light penetration to such a degree as in Cointzio reservoir, where Secchi disk depths rarely exceed $0.2 \mathrm{~m}$ (Susperregui et al., 2009). Our results showed that gullies 
developed in Acrisols provide the bulk of fine particles to the reservoir, even if they occupy less than $0.5 \%$ of the catchment area (Mendoza and Lopez, 2007). In this context, it is clear that mitigation efforts concentrated in areas sensitive to soil erosion could lead to a rapid improvement of water quality in the catchment and, more importantly, in the Cointzio reservoir.

In future, the expected decrease in rain and the increase in temperature should result in an increase in aridity and in surface runoff (Gratiot et al., 2010), which will certainly complicate the implementation of soil conservation measures already tested in the area such as the introduction of a crop rotation and the use of a crop residue cover on the soil (BravoEspinoza et al, 2009). In this context, it is urgent to test some complementary mitigating strategies to stabilize specific gullies and to evaluate their effectiveness, before generalizing their installation across the entire Cointzio catchment (Martinez-Palacios et al., 2011).

\section{Conclusions}

Land degradation is intense in tropical regions, such as in volcanic highlands of central Mexico. Two fingerprinting approaches were conducted to outline the main sources delivering sediment leading to the siltation of Cointzio reservoir draining a $630-\mathrm{km}^{2}$ catchment. This study was conducted in three subcatchments $\left(3-12 \mathrm{~km}^{2}\right)$ representative of the different environments observed in this area. Both fingerprinting methods provided similar results in Huertitas catchment, covered with Acrisols, where sediment was almost exclusively delivered by gullies. In La Cortina, characterized by Andisols, sediment was supplied by cropland. However, results provided by both methods in Potrerillos, covered with a mix of Andisols and Acrisols, strongly differed. Furthermore, massive export of sediment rich in organic matter produced by cattle activity and trampling during the dry season by the first heavy storm of the year is suspected in this subcatchment. This study thereby outlined several difficulties encountered when conducting fingerprinting studies in this type of volcanic catchments. First, soils are very altered in this region, complicating the choice of relevant geochemical fingerprint properties. Second, the DRIFTS-PLS method proved to be very sensitive to the soil content in organic matter. Nevertheless, in a second step, our study could demonstrate the dominant contribution of Acrisols to the sediment delivered from the entire $630-\mathrm{km}^{2}$ catchment to the Cointzio reservoir. Soil conservation measures should therefore focus on stabilizing gully networks as the ones observed in Huertitas catchment as well as on implementing alternative farming practices in Potrerillos-like areas. In the future, 
both fingerprinting methods could usefully be applied to trace sediment in different environments, and solutions to decrease the potential DRIFTS-PLS method sensitivity to soil organic matter content should be investigated.

\section{Acknowledgements}

This is the LSCE contribution No. X. This work is a part of the STREAMS (Sediment TRansport and Erosion Across Mountains) project, funded by the French National Research Agency (ANR/ BLAN06-1_139157) and DESIRE (Desertification, mitigation and land Restoration) project funded by European Union. The authors are also very grateful to Dr. Christine Hatté for conducting the test $\delta^{13} \mathrm{C}$ measurements.

\section{References}

Balesdent, J., Wagner, G.H., 1988. Soil organic matter in long term field experiments as revealed by ${ }^{13} \mathrm{C}$ natural abundance. Soil Science Society of America Journal 52 (118-124).

Barton, A. P., Fullen, M. A., Mitchell, D. J., Hocking, T. J., Liguang Liu, Zhi Wu Bo, Yi Zheng, Zheng Yuan Xia, 2004. Effects of soil conservation measures on erosion rates and crop productivity on subtropical Ultisols in Yunnan Province, China. Agriculture, Ecosystems \& Environment 104(2), 343-357.

Bravo-Inclan, L.A., Saldana-Fabela, M.P. and Sanchez-Chavez, J.J., 2008. Long term eutrophication diagnosis of a high altitude body of water, Zimapan reservoir, Mexico. Water Science \& Techn., 57(11), 1843-1849.

Bravo-Espinoza, M., Mendoza, M.E., Medina-Orozco, L., Prat, C., Garcia-Oliva, F. LopezGranados, E., 2009. Runoff, soil loss and nutrient depletion Ander traditional and alternative cropping systems in the Transmexican volcanic belt, Central Mexico. Land Degradation and development DOI : 10.1002/klr.953

Cavoleda, S., Gallardo, J.F., García-Oliva, F., Kirchmann, H., Prat, C., Bravo, M., Etchevers, J. D., 2011. Land-use effects on the distribution of soil organic carbon within particle-size fractions of volcanic soils in the Transmexican Volcanic Belt (Mexico). Soil Use and Management, 27, 186-194.

Collins, A.L., Walling, D.E., Sichingabula, H.M., Leeks, G.J.L., 2001. Suspended sediment source fingerprinting in a small tropical catchment and some management implications. Applied Geography, 21 (4), 387-412.

Collins, A., Walling, D., 2002. Selecting fingerprint properties for discriminating potential suspended sediment sources in river basins. Journal of Hydrology, 261, 218-244.

Descroix, L., González Barrios, J.L., Viramontes, D., Poulenard, J., Anaya, E., Esteves, M., Estrada, J., 2008. Gully and sheet erosion on subtropical mountain slopes: Their respective roles and the scale effect. Catena, 72(3), 325-339. 
Duvert, C., Gratiot, N., Evrard, O., Navratil, O., Némery, J., Prat, C., Esteves, M., 2010.

Drivers of erosion and suspended sediment transport in three contrasted headwater catchments of the Mexican Central Highlands. Geomorphology 123, 243-256.

Duvert, C., Gratiot, N., Némery, J., Burgos, A., Navratil, O., 2011. Sub-daily variability of suspended sediment fluxes in small mountainous catchments - implications for communitybased river monitoring. Hydrol. Earth Syst. Sci. 15, 703-713.

Evrard, O., Némery, J., Gratiot, N., Duvert, C., Ayrault, S., Lefèvre, I., Poulenard, J., Prat, C., Bonté, P., Esteves, M., 2010. Sediment dynamics during the rainy season in tropical highland catchments of central Mexico using fallout radionuclides. Geomorphology 124, 42-54.

Evrard, O., Navratil, O., Ayrault, S., Ahmadi, M., Némery, J., Legout, C., Lefèvre, I., Poirel, A., Bonté, P., Esteves, M., 2011. Combining suspended sediment monitoring and fingerprinting to trace the spatial origin of fine sediment in a mountainous river catchment. Earth Surface Processes \& Landforms 36, 1072-1089.

FAO, 2006. World Reference Base for Soil Resources 2006. A Framework for International

Gratiot, N., Duvert, C., Collet, L., Vinson, D., Némery, D., Saenz-Romero, C., 2010. Increase in surface runoff in the central mountains of Mexico: lessons from the past and predictive scenario for the next century. Hydrol. Earth Syst. Sci. 14 (2), 291-300.

Le Cloarec, M.F., Bonté, P.H., Lestel, L., Lefèvre, I., Ayrault, S., 2011. Sedimentary record of metal contamination in the Seine River during the last century. Physics \& Chemistry of the Earth, Parts A/B/C 36(12), 515-529.

Mano, V., Nemery, J., Belleudy, P., Poirel, A., 2009. Assessment of suspended sediment transport in four Alpine watersheds (France): influence of the climatic regime. Hydrological Processes 23, 777-792.

Martínez-Carreras, N., Udelhoven, T., Krein, A., Gallart, F., Iffly, J.F., Ziebel, J., Hoffmann, L., Pfister, L., Walling, D.E., 2010a. The use of sediment colour measured by diffuse reflectance spectrometry to determine sediment sources: Application to the Attert River catchment (Luxembourg). Journal of Hydrology, 382 (1-4), 49-63.

Martínez-Carreras, N., Krein, A., Gallart, F., Iffly, J.F., Pfister, L., Hoffmann, L., Owens, P.N., 2010b. Assessment of different colour parameters for discriminating potential suspended sediment sources and provenance: A multi-scale study in Luxembourg. Geomorphology, 118 (1-2), 118-129.

Martínez-Palacios, A., Prat, C., Rios, E., 2011. Use of native Agave to recover the degraded lands and to control soil erosion in the perspective of production of Mescal (Cointzio basin, Michoacan, Mexico). Workshop and soil and water resources preservation, 11-12 October 2011 Grenoble (France).

Mendoza, M.E. and Lopez-Granados, E., 2007. Caracterización físico-geográfica de la subcuenca de Cointzio, Michoacán: Información básica para el manejo integrado de cuencas. 
En: Sánchez- Brito, C., E. Fragoso-Tirado y M. Bravo-Espinoza, Bases Metodológicas para el Manejo Integrado de Cuencas Hidrológicas. Libro Técnico INIFAP. INIFAP. (ISBN 978-97043-0263-4).

Merino-Ibarra, M., Monroy-Rios, E., Vilaclara, G., Castillo, F.S., Gallegos, M.E., RamirezZierold, J., 2008. Physical and chemical limnology of a wind-swept tropical highland reservoir. Aquat Ecol, 2008, 273-320.

Meybeck, M., Laroche, L., Dürr, H.H., Syvitski, J.P.M., 2003. Global variability of daily total suspended solids and their fluxes in rivers. Global \& Planetary Change 39, 65-93.

Nyssen, J., Poesen, J., Moeyersons, J., Deckers, J., Haile, M., Lang, A., 2004. Human impact on the environment in the Ethiopian and Eritrean highlands - a state of the art. Earth-Science Reviews 64(3-4), 273-320.

Owens, P.N., Batalla, R.J., Collins, A.J., Gomez, B., Hicks, D.M., Horowitz, A.J., Kondolf, G.M., Marden, M., Page, M.J., Peacock, D.H., Petticrew, E.L., Salomons, W., Trustrum, N.A., 2005. Fine-grained sediment in river systems: Environmental significance and management issues. River Research \& Applications 21, 693-717.

Poulenard, J., Perrette, Y., Fanget, F., Quetin, P., Trevisan, D., Dorioz, J.M., 2009. Infrared spectroscopy tracing of sediment sources in a small rural watershed (French Alps). Science of the Total Environment 407, 2808-2819.

Poulenard, J., Legout, C., Némery, J., Bramorski, J., Navratil, O., Douchin, A., Fanget, B., Perrette, Y., Evrard, O., Esteves, M., in press. Tracing sediment sources during floods using Diffuse Reflectance Infrared Fourier Transform Spectrometry (DRIFTS): A case study in a highly erosive mountainous catchment (Southern French Alps). Journal of Hydrology.

Quinton, J., Govers, G., Van Oost, K., Bardgett, R.D., 2010. The impact of agricultural soil erosion on biogeochemical cycling. Nature Geoscience, 3: 311-314.

Ramirez-Olvera M. A., Diaz-Arguero, M., Lopez-Lopez., E., 2004. Planktonic crustacean assemblages in a system of three reservoirs in the Mexican Central Plateau: Seasonal and spatial patterns. Journal of Freshwater Ecology 19, 25-34.

Robertson GP, Coleman DC, Bledsoe CS, Sollins P., 1999. Standard soil methods for longterm ecological research Oxford University Press, New York Oxford. 480 pp.

Roldán, A., Caravaca, F., Hernández, M. T., García, C., Sánchez-Brito, C., Velásquez, M., Tiscareño, M., 2003. No-tillage, crop residue additions, and legume cover cropping effects on soil quality characteristics under maize in Patzcuaro watershed (Mexico). Soil \& Tillage Research, 72(1), 65-733.

Sánchez-Chardi, A., Oliveira Ribeiro, C. A., Nadal, J., 2009. Metals in liver and kidneys and the effects of chronic exposure to pyrite mine pollution in the shrew Crocidura russula inhabiting the protected wetland of Doñana. Chemosphere 76(3), 387-394. 
Severo, J.B., Lopez-Lopez, E., Stanley, K.A.B., 2002. Spatial and temporal variation patterns of a waterfowl community reservoir system of the Central Plateau, Mexico. Hydrobiologia, 467, 123-131.

Susperregui, A.S., Gratiot, N., Esteves, M. \& Prat C., 2009. A preliminary hydrosedimentary view of the highly turbid, tropical, manmade lake: Cointzio Reservoir (Michoacan, Mexico). Lakes \& reservoirs: Research \& Management 14, 31-39.

Syvitski, J.P.M., Vörösmarty, J.V., Kettner, A.J., Green, P., 2005. Impacts of humans on the flux of terrestrial sediments to the global coastal ocean. Science 308, 376-380.

Takeda, A., Kimura, K., Yamasaki, S., 2004. Analysis of 57 elements in Japanese soils, with special reference to soil group and agricultural use. Geoderma 119, 291-307.

Tamtam, F., LeBot, B., Dinh, T., Mompelat, S., Eurin, J., Chevreuil, M., Bonté, P., Mouchel, J.-M., Ayrault, S., 2011. A 50-year record of quinolone and sulphonamide antimicrobial agents in Seine River sediments. Journal of Soils and Sediments 11, 852-859.

Urban, J.D., Tachovsky, J.A., Haws, L.C., Wikoff Staskal, D., Harris, M.A., 2009. Assessment of human health risks posed by consumption of fish from the Lower Passaic River, New Jersey. Science of the Total Environment 408 (2), 209-224.

Wallbrink, P.J., Murray, A.S., 1993. Use of fallout radionuclides as indicators of erosion processes. J. Hydrol. Proc. 7, 297-304.

Walling, D.E., 2005. Tracing suspended sediment sources in catchments and river systems. Science of the Total Environment 344, 159-184.

660 Santiago Undameo station within the Cointzio catchment in the tropical highlands of central

661 Mexico. Areas characterized by different soil types are also delineated, and locations where

662 composite soil samples were collected are indicated. This study focused on the samples

663 collected within the boundaries of the monitored subcatchments.

664

665 Figure 2. Sediment sources in Huertitas catchment as defined by conventional and alternative

666 fingerprinting techniques. Please note that, because of logistical problems to conduct the

667 sample irradiations, results derived from the conventional mixing model are only available for

668 the five first composite river sediment samples of the season.

670 Figure 3. Sediment sources in La Cortina catchment as defined by conventional and

671 alternative fingerprinting techniques. 
673 Figure 4. Sediment sources in Potrerillos catchment as defined by conventional and

674 alternative fingerprinting techniques.

675

676

677

678

679

680

681

682

683

684

685

686

687

688

689

690

691

692

693

694

695

696

697

698

699
Figure 5. Relationship between contribution of rangeland topsoil and suspended sediment organic carbon content at the outlet of Potrerillos subcatchment. Carbon content of sediment collected during the 1/7/2009 flood constitutes an outlier (probably explained by the massive export of cow dung stored on the soil surface by the first heavy storm of the season).

Figure 6. Values of U/Th ratio measured in riverbed sediment samples collected along the river network within the entire catchment ( $\mathrm{U}$ corresponds to activities in Ra-226, and Th to activities in Ra-228).

Figure 7. Typical spectra of Andisols, Acrisols and suspended sediment collected at Santiago Undameo station.

Figure 8. Contribution of Acrisols to sediment monitored at Santiago Undameo station.

Discharge values correspond to mean discharges measured during the sediment collection period by the trap. 
Tables

Table 1

Altitude, soil, slope, and erosion characteristics of the study sites

\begin{tabular}{|c|c|c|c|c|}
\hline Subcatchment & Area $\left(\mathrm{km}^{2}\right)$ & Altitude range $(\mathrm{m})$ & Soil types ${ }^{a}$ & $\begin{array}{l}\text { Severely eroded areas }{ }^{\mathrm{b}} \\
\text { ( } \% \text { of the catchment surface) }\end{array}$ \\
\hline Huertitas & 3 & $2150-2450$ & Acrisols (100\%) & 6 \\
\hline La Cortina & 9 & $2250-2700$ & Andisols (100\%) & 0 \\
\hline Potrerillos & 12 & $2200-2700$ & $\begin{array}{l}\text { Acrisols }(60 \%) \\
\text { Andisols }(40 \%)\end{array}$ & 1 \\
\hline Undameo & 630 & $2000-3440$ & $\begin{array}{l}\text { Andisols (37\%) } \\
\text { Luvisols } \\
\text { Acrisols (33\%) }\end{array}$ & 0.5 \\
\hline
\end{tabular}

\section{${ }^{a}$ According to FAO (2006).}

${ }^{\mathrm{b}}$ Derived from the analysis of aerial photographs. 
Table 2

Geochemical $\left(\mathrm{g} \mathrm{kg}^{-1}\right)$, radionuclide $\left(\mathrm{Bq} \mathrm{kg}^{-1}\right)$, organic matter $(\%)$ and grain size properties of the sediment source samples.

\begin{tabular}{|c|c|c|c|c|c|c|c|c|c|c|c|c|c|c|c|c|c|c|c|c|c|c|c|c|c|c|c|}
\hline Huertitas & & $n$ & & $\mathrm{Na}$ & As & & $\mathrm{Yb}$ & $\mathrm{Hf}$ & & $\mathrm{Tb}$ & Sc & $\mathrm{Ta}$ & Cs & Co & $\mathrm{Eu}$ & $|x s-P b-210|$ & $\mathrm{Pb}-210$ & Th-234 I & Ra-226 & Ra-228 & Th-228 & s-137 & $\% \mathrm{C}$ & $\% \mathrm{~N}$ & $\% \mathrm{C}(\mathrm{CaCO} 3)$ & $\%<63 \mu \mathrm{m}$ & $\mathrm{d} 50(\mu \mathrm{m})$ \\
\hline \multirow{2}{*}{ Gullies } & mean & 6 & 0.0 & 0.0 & 2.3 & 6.2 & 2.5 & 6.2 & 6.8 & 0.5 & 23.7 & 1.0 & 0.9 & 20.7 & 0.9 & 0.0 & 17.0 & 23.4 & 23.7 & 24.2 & 24.2 & 0.0 & 0.34 & 0.03 & $<0,01$ & 95 & 12 \\
\hline & variance & & 0.0 & 0.0 & 1.5 & 1.9 & 0.2 & 1.1 & 0.1 & 0.1 & 1.5 & 0.5 & 0.8 & 9.9 & 0.0 & 0.0 & 20.0 & 23.3 & 31.3 & 38.1 & 34.6 & 0.0 & 0.28 & 0.03 & & 1 & 2 \\
\hline \multirow{2}{*}{ Cropland } & mean & 3 & 0.4 & 0.2 & 2.0 & 7.1 & 2.9 & 7.1 & 6.4 & 0.9 & 20.0 & 0.8 & 1.8 & 30.1 & 1.0 & 8.0 & 34.0 & 32.5 & 26.1 & 27.2 & 27.7 & 1.3 & 2.73 & 0.21 & $<0,01$ & 88 & 17 \\
\hline & variance & & 0.0 & 0.0 & 5.7 & 3.9 & 0.0 & 0.4 & 0.1 & 0.0 & 0.3 & 0.8 & 4.3 & 43.2 & 0.0 & 5.1 & 63.2 & 19.3 & 36.7 & 48.1 & 65.8 & 0.9 & 0.75 & 0.06 & & 1 & 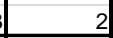 \\
\hline \multirow{3}{*}{$\begin{array}{l}\text { La Cortina } \\
\text { Cropland }\end{array}$} & & & & & & & & & & & & & & & & & & & & & & & & & & & \\
\hline & Mean & 2 & 0.1 & 0.1 & 6.4 & 9.4 & 3.0 & 8.7 & 7.2 & 1.0 & 22.3 & 2.1 & 5.0 & 21.5 & 1.4 & 16.2 & 49.8 & 38.1 & 33.7 & 36.8 & 37.4 & 3.7 & 6.31 & 0.43 & 0.02 & 89 & 19 \\
\hline & Variance & & 0.0 & 0.0 & 1.1 & 3.7 & 0.1 & 1.3 & 0.2 & 0.0 & 0.2 & 0.9 & 0.2 & 16.2 & 0.1 & 5.3 & 6.6 & 14.0 & 23.9 & 10.8 & 10.8 & 0.3 & 0.14 & .03 & 0.01 & 11 & 10 \\
\hline \multirow[t]{2}{*}{ Woodland } & Mean & 2 & 0.2 & 0.1 & 5.5 & 9 & 2 & 7.7 & 2 & 1.2 & 23.7 & 1.3 & 5.1 & 25 & 1.6 & 81.0 & 37.1 & 37.8 & 32.8 & 36.1 & 36.8 & 6.6 & 9.94 & 0.50 & 0.01 & 81 & 26 \\
\hline & Variance & & 0.0 & 0.0 & 0.3 & 0.4 & 0.1 & 0.4 & 0.4 & 0.1 & 1.2 & 0.1 & 0.3 & 1.3 & 0.1 & 62.0 & 1.9 & 1.9 & 1.6 & 1.8 & 1.8 & 0.3 & 5.6 & 0.1 & 0.01 & & 2 \\
\hline \multicolumn{28}{|c|}{\begin{tabular}{|l|} 
Potrerillos \\
\end{tabular}} \\
\hline \multirow[t]{2}{*}{ Gullies } & Me & 2 & 0.7 & 0.9 & 0.0 & 8.0 & 2.4 & 8.2 & 2 & 1.6 & 17.3 & 1.8 & 4.5 & 29.2 & 1.3 & 0 & 17.2 & 32.0 & 23.1 & 32.2 & 32.8 & 1.3 & 0.13 & 0.01 & $<0,01$ & 83 & 25 \\
\hline & Variance & & 0.0 & 0.1 & 0.0 & 0.0 & 0.0 & 1.0 & 1 & 0.4 & 1.6 & 0.0 & 6.8 & 15.4 & 0.0 & 0 & 4.0 & 6.3 & 8.5 & 1.9 & 3. & 2.1 & 0. & .02 & & 11 & -4 \\
\hline \multirow[t]{2}{*}{ Cropland } & Mean & 2 & 0.4 & 0.4 & 3.2 & 6.8 & 2.5 & 6.0 & 6.1 & 0.5 & 17.3 & 2.2 & 1.6 & 27.0 & 0.9 & 7.0 & 30.0 & 33.7 & 23.8 & 31.6 & 32.1 & 1.4 & 1.43 & 0.11 & $<0,01$ & 82 & 22 \\
\hline & Variance & & 0.0 & 0.0 & 0.3 & 0.0 & 0.0 & 0.1 & 2.8 & 0.4 & 3.3 & 0.4 & 3.4 & 37.0 & 0.0 & 10.0 & 53.3 & 3.2 & 13.2 & 0.1 & 0.3 & 0.9 & 0.74 & 0.07 & & 11 & 12 \\
\hline
\end{tabular}


Table 3

758

Geochemical $\left(\mathrm{g} \mathrm{kg}^{-1}\right)$, radionuclide $\left(\mathrm{Bq} \mathrm{kg}^{-1}\right)$, organic matter $(\%)$ and grain size properties of the river sediment samples.

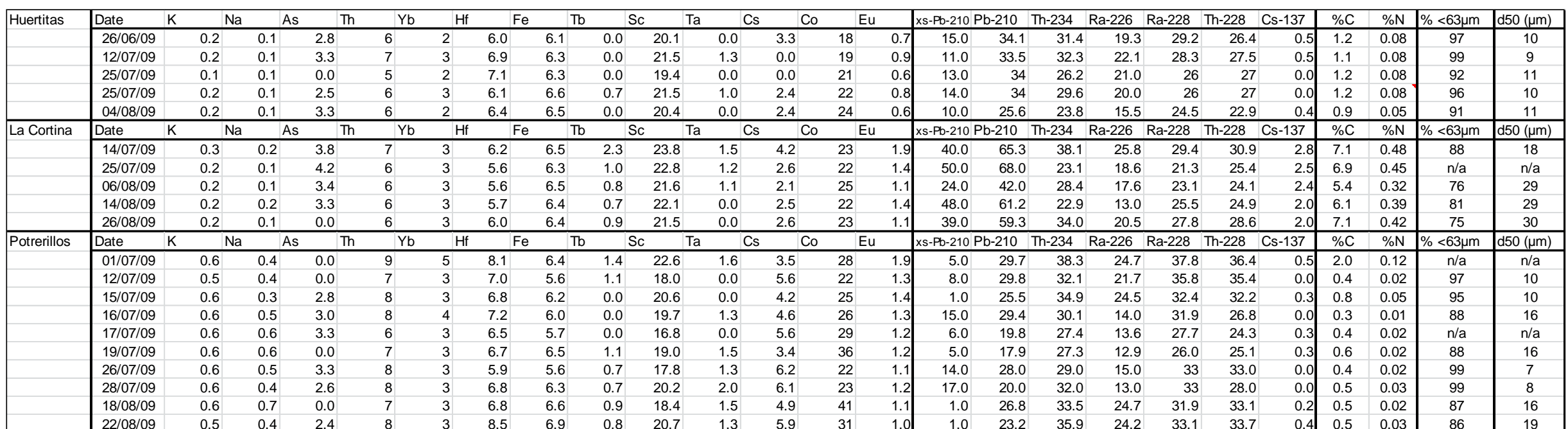


Table 4

Discriminant properties in the three study sites (Wilk's lambda and percentage of correctly classified samples)

\begin{tabular}{lll}
\hline $\begin{array}{l}\text { Fingerprint property } \\
\text { added }\end{array}$ & Wilk's lambda & $\begin{array}{l}\text { Cumulative \% of } \\
\text { samples classified } \\
\text { correctly }\end{array}$ \\
&
\end{tabular}

(a) Huertitas subcatchment

$\begin{array}{lrr}\mathrm{C} & 0.0192 & 96 \\ \mathrm{xs}-\mathrm{Pb}-210 & 0.0096 & 98 \\ \mathrm{Cs}-137 & 0.0048 & 100\end{array}$

(b) La Cortina subcatchment

$\begin{array}{lll}\mathrm{xs}-\mathrm{Pb}-210 & 5.88 \mathrm{E}-15 & 100\end{array}$

Cs-137 $9.81 \mathrm{E}-17 \quad 100$

(c) Potrerillos subcatchment

$\begin{array}{lll}\mathrm{C} & 1.07 \mathrm{E}-16 & 100 \\ \mathrm{xs}-\mathrm{Pb}-210 & 2.18 \mathrm{E}-17 & 100\end{array}$


Table 5

809 Predictive performance of the PLS (Partial Least Squares) models in the different Mexican subcatchments

\begin{tabular}{|l|l|l|l|l|l|l|}
\hline Sub-catchment & $\begin{array}{l}\text { Number } \\
\text { of mixture } \\
\text { samples }\end{array}$ & $\begin{array}{l}\text { Considered } \\
\text { sources of } \\
\text { sediments }\end{array}$ & $\mathrm{R}^{2}$ & RMSEC & RMSEP & RMESCV \\
\hline Huertitas & 20 & $\begin{array}{l}\text { Gullies } \\
\text { Cropland }\end{array}$ & 0.99 & 2.38 & 4.49 & 6.13 \\
& & Forest Road & 0.99 & 1.18 & 2.43 & 6.64 \\
\hline La Cortina & 32 & Cropland & 0.99 & 2.96 & 8.66 & 6.67 \\
\hline Potrerillos & 22 & Gullies & 0.99 & 0.321 & 11.1 & 11.1 \\
& & Cropland & 0.98 & 5.04 & 7.46 & 6.73 \\
\hline Undameo & 22 & Acrisols & 0.99 & 4.08 & 2.24 & 13.2 \\
& & Andisols & 0.99 & 5.21 & 3.41 & 13.6 \\
\hline
\end{tabular}

811 


\section{[S180] Tracing sediment sources in a tropical highland catchment of central Mexico by using conventional and alternative fingerprinting methods}

\begin{tabular}{|r|l|}
\hline Journal: & Hydrological Processes \\
\hline Manuscript ID: & HYP-11-0762.R1 \\
\hline Date Submitted by the Author: & n/a \\
\hline Complete List of Authors: & $\begin{array}{l}\text { Evrard, Olivier; CEA, LSCE } \\
\text { Poulenard, Jerome } \\
\text { Nemery, Julien; G-INP, LTHE } \\
\text { Ayrault, Sophie; CEA, LSCE } \\
\text { Gratiot, Nicolas; IRD, LTHE } \\
\text { Duvert, Clement; IRD, LTHE } \\
\text { Prat, Christian; IRD, LTHE } \\
\text { Lefévre, Irène; CEA, LSCE } \\
\text { Bonté, Philippe; CEA, LSCE } \\
\text { Esteves, Michel; IRD, LTHE }\end{array}$ \\
\hline Keywords: & sediment, fingerprinting, soil types, Mexico, tropical catchment \\
\hline
\end{tabular}

SCHOLARONE ${ }^{m}$

Manuscripts 
Figure 1

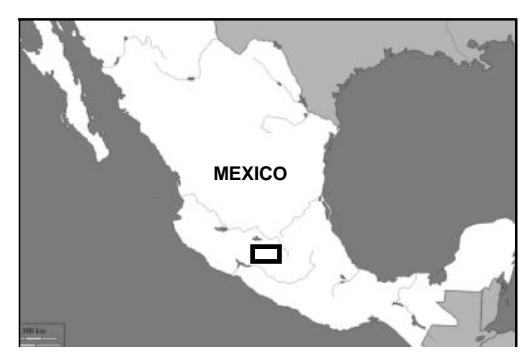

\section{Legend}

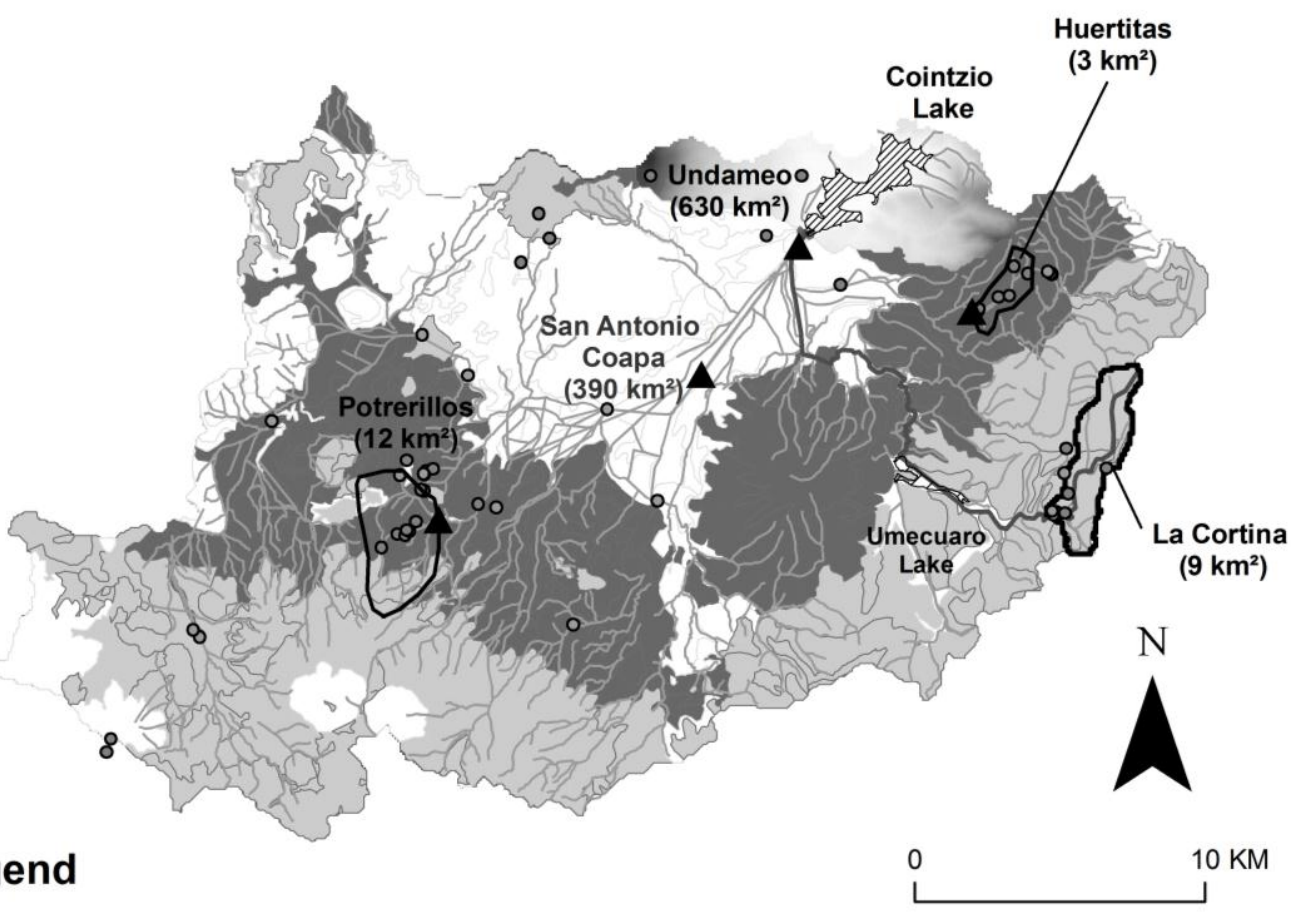

A River/rainfall monitoring station

- Composite soil samples

—_ Rio Grande de Morelia

Other rivers

Monitored subcatchment

Soil types

\begin{tabular}{|l}
\hline Acrisols \\
\hline Andisols \\
\hline Other soil types
\end{tabular}




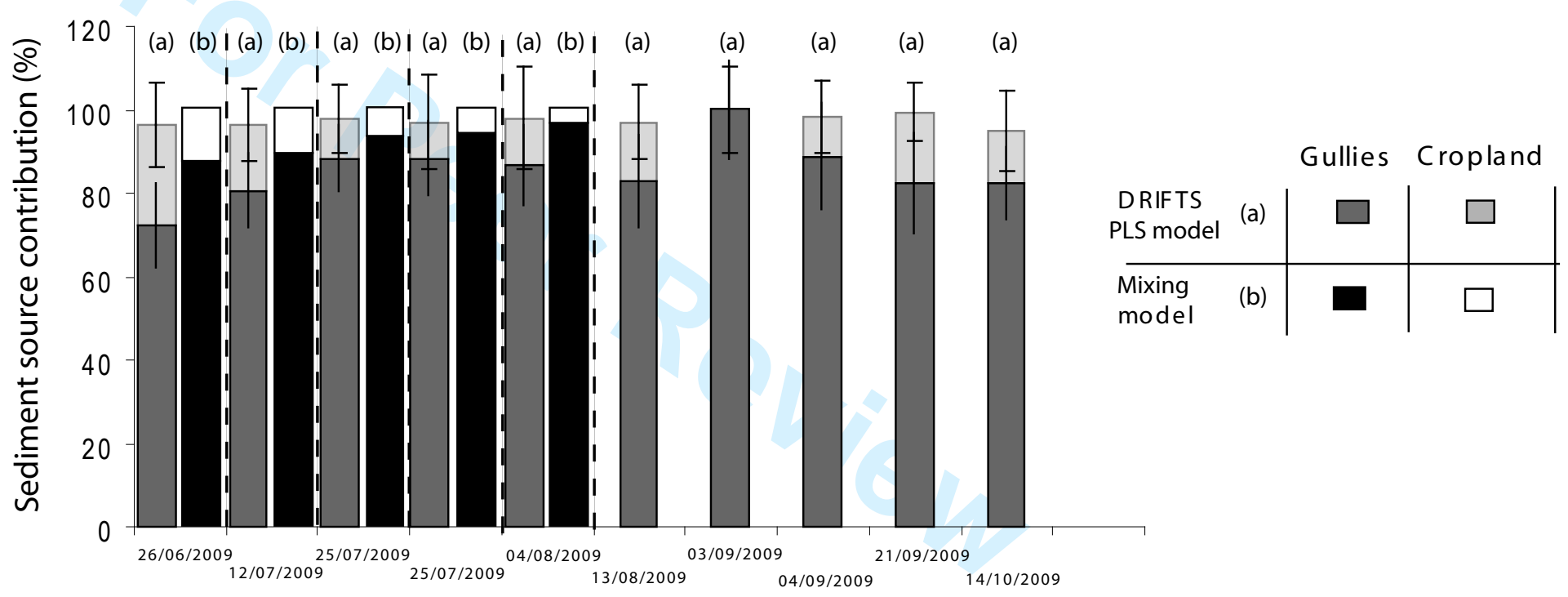




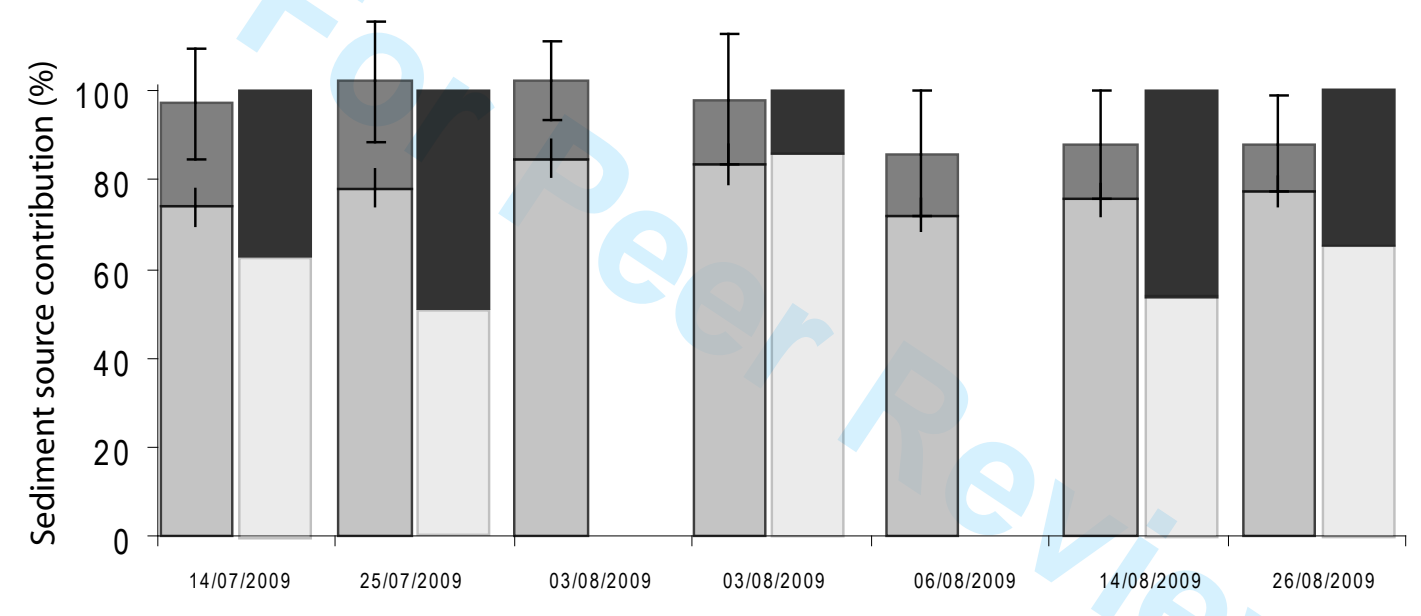

Cropland Woodland

\begin{tabular}{ll|l|l|}
$\begin{array}{l}\text { DRIFTS (a) } \\
\text { PLS model }\end{array}$ & $\square$ & $\square$ \\
\hline $\begin{array}{l}\text { Mixing (b) } \\
\text { model }\end{array}$ & $\square$ &
\end{tabular}




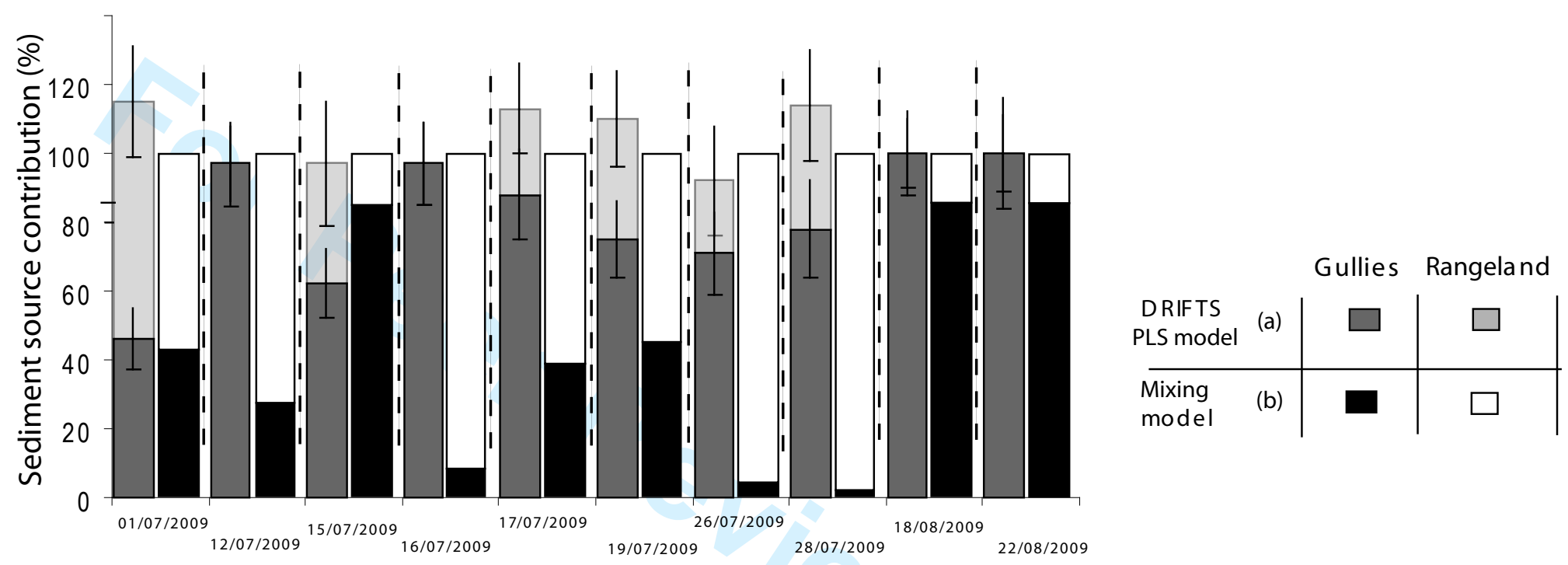


Figure 5.

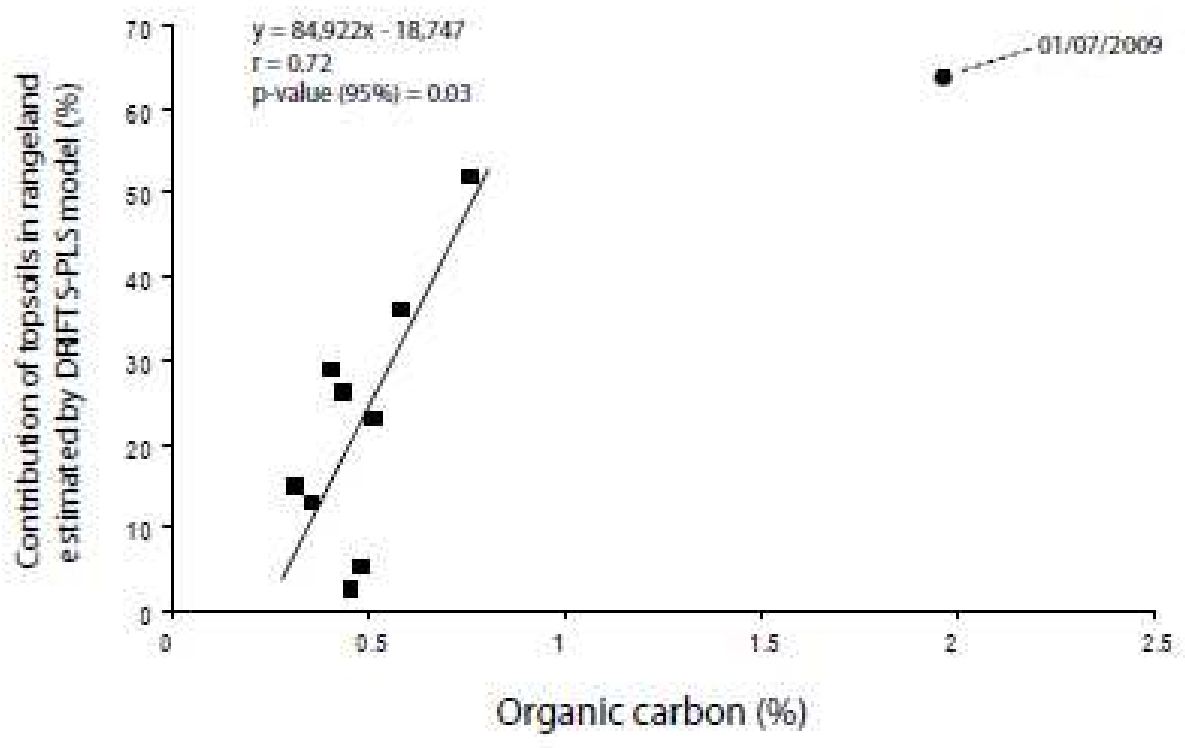

http://mc.manuscriptcentral.com/hyp 
Figure 6. Values of $U / T h$ ratio measured in riverbed sediment samples collected along the river network within the entire catchment (U corresponds to activities in Ra-226, and Th to activities in Ra-228).

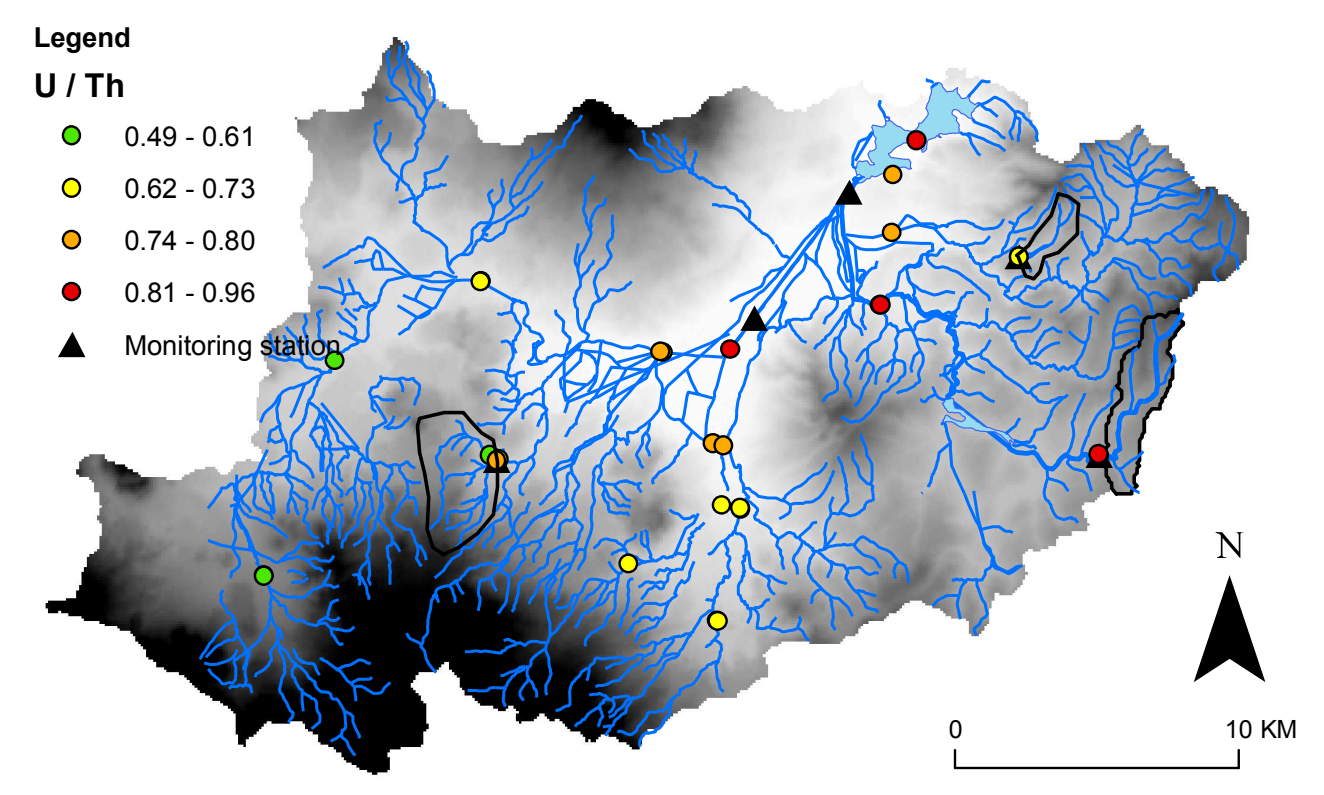


Figure 7.

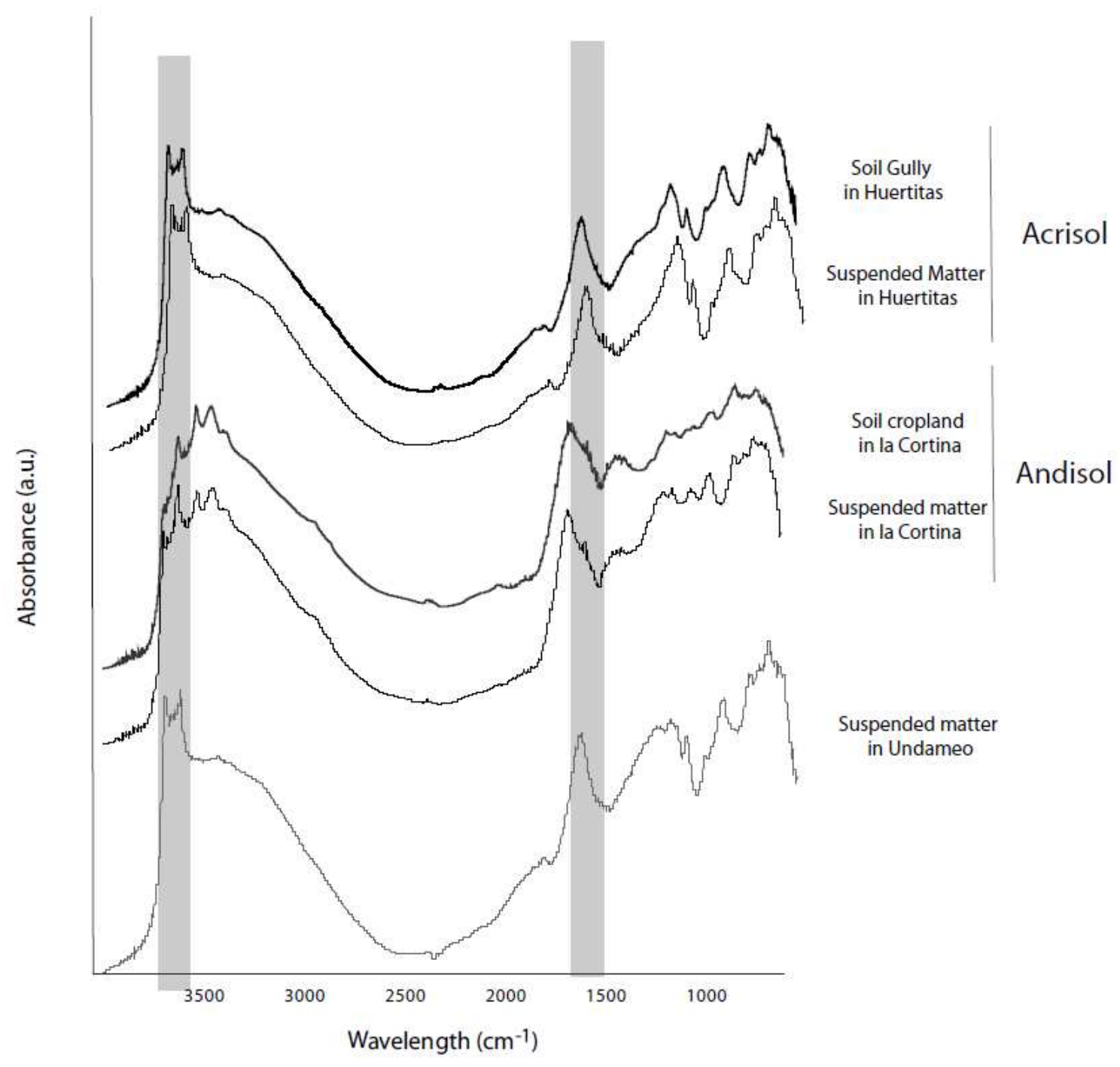

38
39

40

41

42

43

44

45

46

47

48

49

50

51

52

53

54

55

56

57

58

59

60

http://mc.manuscriptcentral.com/hyp 
Figure 8.
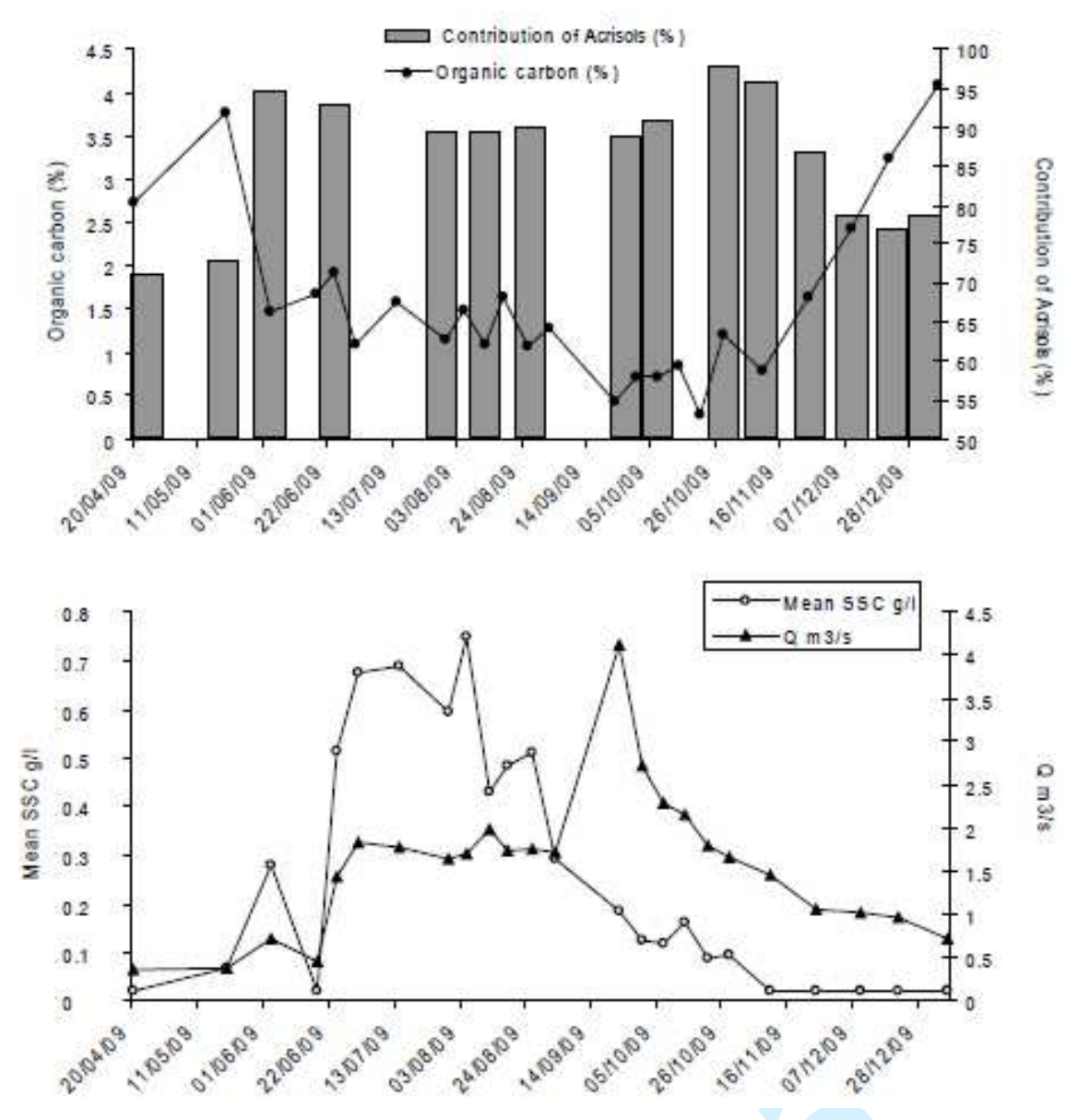

http://mc.manuscriptcentral.com/hyp 